\title{
Perception of women with breast cancer undergoing chemotherapy: a comprehensive analysis
}

\author{
Percepção de mulheres com câncer de mama em quimioterapia: uma análise compreensiva \\ Percepción de mujeres con cáncer de mama en quimioterapia: un análisis exhaustivo
}

\section{Marlise Barros de Medeiros' \\ ORCID: 0000-0002-7813-6296}

Rose Mary Costa Rosa Andrade Silva'

ORCID: 0000-0002-6403-2349

Eliane Ramos Pereira'

ORCID: 0000-0002-6381-3979

Sérgio Henrique da Silva Melo' ORCID: 0000-0002-8088-5982

Fabiana Lopes Joaquim'

ORCID: 0000-0003-1344-2740

Bianca Marques dos Santos' ORCID: 0000-0002-2123-5744

Ticiane Roberta Pinto Goés' ORCID: 0000-0001-5686-9176

'Universidade Federal Fluminense. Niterói, Rio de Janeiro, Brazil.

How to cite this article:

Medeiros MB, Silva RMCRA, Pereira ER, Melo SHS, Joaquim FL, Santos BM, et al. Perception of women with breast cancer undergoing chemotherapy: a comprehensive analysis. Rev Bras Enferm. 2019;72(Suppl 3):103-10. doi: http://dx.doi.org/10.1590/0034-7167-2018-0165

\section{Corresponding Author: \\ Marlise Barros de Medeiros E-mail: marlisemedeiros@gmail.com}

Submission: 07-25-2018 Approval: 07-26-2018

\begin{abstract}
Objective: To comprehensively analyze the perception of women with breast cancer on the experience of undergoing chemotherapy. Method: This was a qualitative, descriptive, phenomenological study, supported by the Merleau-Ponty philosophy. It was conducted in a chemotherapy outpatient clinic with 20 participants who completed a phenomenological interview. Results: The phenomenological data analysis demonstrated that the perception of women about the experience of chemotherapy is about change, not only of the physical body, but of their identity, and that it considers existential aspects. Three categories emerged from the experience of alopecia, fatigue, and spirituality, respectively: the body itself, the current and habitual body, and transcendence. Final considerations: Bodily changes, and the existential implications perceived by the women in this study, analyzed from the Merleau-Ponty perspective, makes it possible to consider body concept, and provides support for humanized care based on singularity and the socio-cultural context. Descriptors: Breast Neoplasms; Drug Therapy; Nursing Care; Oncology Nursing; Philosophy Nursing.
\end{abstract}

\section{RESUMO}

Objetivo: Analisar compreensivamente a percepção de mulheres com câncer de mama sobre a vivência da quimioterapia. Método: Trata-se de um estudo de natureza qualitativa, descritivo, do tipo fenomenológico, respaldado na filosofia de Merleau-Ponty. Foi realizado em um ambulatório de quimioterapia e contou com 20 participantes que foram submetidas a entrevista fenomenológica. Resultados: A partir da análise fenomenológica dos dados, compreendeu-se que a percepção das mulheres sobre a vivência da quimioterapia é de mudança, não só de corpo físico, mas de identidade e alcança aspectos existenciais. A partir da vivência da alopecia, fadiga e espiritualidade emergiram três categorias respectivamente: 0 corpo próprio, o corpo atual e habitual e a transcendência. Considerações finais: A mudança de corpo e suas implicações existenciais percebidas pelas mulheres no estudo, analisadas sob a ótica Merleau-Pontyana, possibilitam abranger a concepção de corpo, fornecendo subsídios para o cuidado humanizado a partir da singularidade e do contexto sociocultural.

Descritores: Neoplasias da Mama; Tratamento Farmacológico; Cuidado de Enfermagem; Enfermagem Oncológica; Filosofia em Enfermagem.

\section{RESUMEN}

Objetivo: Analizar exhaustivamente la percepción de las mujeres con cáncer de mama sobre la experiencia de la quimioterapia. Método: Este fue un estudio cualitativo, descriptivo, fenomenológico, respaldado por la filosofía Merleau-Ponty realizada en una clínica ambulatoria de quimioterapia con 20 participantes que se sometieron a una entrevista fenomenológica. Resultados: El análisis fenomenológico de los datos demostró que la percepción de las mujeres sobre la experiencia de la quimioterapia tiene que ver con el cambio, no solo del cuerpo físico, sino de la identidad y el alcance de los aspectos existenciales. De la alopecia, fatiga y espiritualidad emergieron tres categorías respectivamente: el cuerpo mismo, el cuerpo actual y habitual y la trascendencia. Consideraciones finales: El cambio del cuerpo y sus implicaciones existenciales percibidas por las mujeres en este estudio, y analizadas bajo la perspectiva de Merleau-Pontyana, permiten cubrir la concepción del cuerpo y proporcionar subsidios para el cuidado humanizado basado en la singularidad y el contexto sociocultural.

Descriptores: Neoplasias de la Mama; Tratamiento Farmacológico; Atención de Enfermería; Enfermería Oncológica; Filosofía en Enfermería. 


\section{INTRODUCTION}

Breast cancer is the most common malignant neoplasm among women, and is also the leading cause of cancer death in the adult female population worldwide. In Brazil, breast cancer is considered a public health problem due to its high incidence and high mortality. When breast cancer is diagnosed early and when timely treatment is received, breast cancer has a relatively good prognosis, with a similar response to chronic disease control, but with better survival ${ }^{(1)}$.

Several factors are related to late diagnosis, among these are: difficulties of accessing the health services, methods of diagnosis, referral within the scope of the Unified Health System (SUS), and the education of the primary health network with regard to orientation for early detection ${ }^{(2-3)}$.

Breast cancer generates distress, from suspicion of the disease to the diagnosis, because of the negative implications of the treatment, and the idea of death associated with cancer ${ }^{(4)}$. Breast cancer treatment can include more than one therapeutic modality, such as surgery, chemotherapy, radiation therapy, hormone therapy, and molecular target therapy, whose adverse effects have led to questions about their gains. In this sense, studies on quality of life have become important in oncology, since the success of cancer treatment should also focus on the qualitative aspect, the perspective of the patient and her tolerance to treatment $t^{(5-6)}$.

Chemotherapy is associated with a worsening of the quality of life of women with breast cancer, as this treatment causes a series of side effects. When chemotherapy is associated with radical mastectomy, the impossibility of breast reconstruction and hormone therapy, worse quality of life scores were identified, especially in young women who tend to value their image, femininity, and expectations about their fertility ${ }^{(7)}$.

According to the World Health Organization, quality of life is "the individual's perception of her position in life, in the context of culture, value systems in which she lives, in relation to her goals, expectations, standards, and concerns"(8). Based on this definition, it was decided to use perception to approach the theme, based on the phenomenological methodology that consists in returning to the same things, that is, life experience, and to try to understand in what way things appear to the subject's consciousness, to reach her essence.

We start from the world of life of each subject who, from what she experiences, presents a unique perspective on her life, considering the complexity that is her own, and that requires a broad understanding that a questionnaire does not capture. In view of the above, the following concern arises: how do women with breast cancer perceive their lives during chemotherapy?

The theme of the study is a priority, encompassing oncology and women's health care, and it is relevant to launch a comprehensive view in this context to support care that focuses on ethics, humanization, and integrality in a highly specialized care setting.

\section{OBJECTIVE}

To comprehensively analyze the perception of women with breast cancer on the experience of chemotherapy, based on the thoughts of Maurice Merleau-Ponty, in his work, The Phenomenology of Perception.

\section{METHOD}

\section{Ethical aspects}

The study was submitted to and approved by the Research Ethics Committee (REC) of the Antônio Pedro University Hospital, in November of 2016. The research followed all the ethical precepts recommended by CNS/MS Resolution 466/12, which deals with aspects related to human research. The selected participants signed the Terms of Free and Informed Consent in duplicate, before data collection began, and to guarantee anonymity, received the code, "P" (participant), followed by Arabic numeration.

\section{Methodological theoretical reference}

Phenomenology was initiated by Husserl (1859-1938) at the end of the century. For him, phenomenology consists of "going back to the same things", it represents the search for the rigorous description of experience as it is, as it appears to consciousness before any theorization about it occurs ${ }^{(9)}$.

It is the mission to clarify themes free of scientific and philosophical presuppositions, from the method of phenomenological reductionism, which consists of leaving the natural way in which we apprehend the facts, seeking a distancing from the world, to analyze the manner of the constitution of the conscious experience, in order to reach its essence ${ }^{(9)}$.

Maurice Merleau-Ponty, writer and philosopher, was a student of Husserl, and led the phenomenological thought in France. The Phenomenology of Perception (1945) consists of his doctoral dissertation, in which he sought to develop an analysis of the subject in the world from the Lebenswelt, which means world-of-life. Merleau-Ponty defined phenomenology as: "[...] the study of essences, and it is also a philosophy that restores the essences in existence, because it does not intend to understand man and the world in any other manner than through its facticity $[. . .]^{\prime \prime(10)}$. The essence is understood in the constant confrontation of the being in the world, in an effective deal with the world, in a certain time and space.

Merleau-Ponty considers phenomenological reductionism as a loosening of ties that bind us to the everyday, to relearn how to look at the world ${ }^{(9)}$. And, from this world, there is no possibility of totally withdrawing conscious thought, because the consciousness itself is incarnated or incorporated, that is, what we think, reflect and know is permeated by sensations coming from our experiences in the world that the body provides.

There is a clear criticism of Merleau-Ponty's conception of the body in the Cartesian perspective, bringing the idea that body and mind are inseparable, as well as the notion of consciousness and world, when affirming that "my whole body is not for me an association of organs juxtaposed in space. I have it in an undivided possession [...]"(10).

In the study, Phenomenology of Perception, Merleau-Ponty attributes to phenomenology the task of clarifying the meaning of concepts we use, with a return to the sources of meaning, characterizing perception as primordial, as it is in perception that these sources will be found ${ }^{(10)}$. Perception, however, occurs by means of a practical involvement with things, not just an idea, but also an experience: an effective action, in view of the dynamic capacity of the body. 
For the intellectualists, perception is related to stimulus-response causality, as it is a rational organization of the sensations. In Gestalt theory, with which Merleau-Ponty sympathized, perception is understood by means of the notion of field, in which there are no elementary sensations or isolated objects. For Gestaltists, perception cannot be reduced to the association of judgments and reasoning. Therefore, perception is not the total knowledge of the object, but an interpretation that is always provisional and incomplete ${ }^{(11)}$.

The phenomenological conception of perception considers that this is an event of corporeality; it is not something static, nor is it a mental representation. In the phenomenological conception of perception, the body as the subject of perception expresses its creative and dynamic capacity, which enables us always to be complemented by different glances about the world ${ }^{(10)}$.

Considering that "[...] from things to the thought of things, the experience is reduced [...]"(10), Merleau-Ponty states that the basis of perception lies in the experience of the subject, as incarnate consciousness and phenomenal body, which feels and recognizes the world considering its history and symbolism. The experiences of the world precede the knowledge about the same.

With this theoretical methodological reference, the study will seek the essences in each narrative, in the unveiling of the phenomenological perception of the woman about her life, body, and world, considering that in each narrative, not only does the language of speech exist, but the body that expresses itself in living and reliving its story, allowing one to perceive her own being.

\section{Study design}

This was a qualitative, descriptive, phenomenological study, supported by the Merleau-Ponty philosophy.

\section{Methodological procedures}

\section{Study setting}

The research was conducted in a private chemotherapy outpatient clinic, located in the city of Rio de Janeiro.

\section{Data source}

The study participants were women with breast cancer undergoing chemotherapy. The inclusion criteria were: women in adjuvant and neoadjuvant chemotherapy treatment, older than 18 years of age. The exclusion criteria were women who: were receiving palliative chemotherapy and/or treatment with exclusive monoclonal antibodies, had psychiatric disorders, or had cognitive disorders that could interfere with interpersonal communication.

\section{Data collection and organization}

Data collection began in November of 2016, after REC approval, and was completed in February of 2017. First, the women receiving chemotherapy treatment were identified by the prior assessment of the schedule of the institution's chemotherapy treatments, the patient's name, and the chemotherapy protocol. First-line chemotherapy protocols for the treatment of breast cancer were selected. By analyzing the scheduling worksheet, women who were treated with exclusive monoclonal antibodies, or who were in palliative treatment were excluded. After the identification of possible study participants, at the time and date of the treatment, they were invited to participate in the study, and the objectives and ethical and legal aspects of the research were clarified. Those who agreed to participate in the study signed the Terms of Free and Informed Consent Form, in duplicate.

A questionnaire was completed with identifying data including: name, age, marital status, occupation, and adjuvant or neoadjuvant chemotherapy. At that time, those with psychiatric alterations and/or cognitive disturbances, which interfered with interpersonal communication, were excluded.

The interview with the guiding question occurred after the venous puncture and beginning of the chemotherapy infusion. The Institution provides the private box treatment for each woman in an armchair, ensuring comfort and privacy during the interview. The guiding question, "How do you perceive your life during chemotherapy treatment?", was used to begin the participant's narrative. Many participants began their statements with the identification of the disease, and those who were on adjuvant chemotherapy also reported the mastectomy experience, relating it to the time of chemotherapy. Data saturation was achieved with 20 interviews, that is, the moment when the essence of the phenomenon was revealed.

\section{Data analysis}

The phenomenological analysis of the data occurred in three steps: description of the phenomenon, reduction, and phenomenological understanding. The description is the revelation of the lived phenomenon, manifested by language, transcribed in the form of a text for appreciation and understanding. The reduction aims to define the essence of the phenomenon described. Phenomenological understanding occurs simultaneously with interpretation ${ }^{(10)}$.

Following the steps, the narratives were transcribed and read repeatedly, so that the woman's perception about her life during chemotherapy was identified in the description of her experience. The reduction consisted of defining units of meaning, those things that, during the narrative, were repeated and which prevailed in the midst of the narratives. The phenomenological understanding consisted of the apprehension of the phenomenon, from its description and reduction. Phenomenological understanding captures the essence of the phenomenon as a set of units of meaning, that is, what persists in the face of the variations that appear in the data ${ }^{(12)}$.

\section{RESULTS}

sWith regards the chemotherapy, 90\% had chemotherapy with anthracycline and taxane, 5\% received a docetaxel and cyclophosphamide protocol; and 5\% received the docetaxel protocol. In relation to the type of treatment, considering the time of surgery, $30 \%$ received neoadjuvant chemotherapy, and 70\% had adjuvant chemotherapy.

The level of education included completed college (60\%), 25\% completed high school, 5\% completed elementary school, and $10 \%$ incomplete elementary education. Regarding age, there 
was a minimum of 32 years and a maximum of 74 years. There was a predominance of those in their 40 s (40\%).

From the phenomenological data analysis, the perception of women about the chemotherapy experience is about changes, not only of the physical body, but also their identity. The main changes that reached the existential level were the experience of alopecia, fatigue, and spirituality. From these changes, three categories emerged, respectively: the body itself, the current and habitual body, and transcendence. From the experience of alopecia emerged considerations about self-image and identity, that Merleau-Ponty understood as the body itself; from the experience of fatigue emerged considerations related to the functions and activities developed prior to chemotherapy, and the current possibilities were analyzed from the perspective of Merleau-Ponty of the current and habitual body; from the limitations experienced we identified experiences of personal ascesis, with the spirituality aiding in revealing transcendence.

\section{Alopecia: considerations about one's own body}

The experience of alopecia was emphasized in all the narratives, as being primarily responsible for the alterations of the woman's self-image during chemotherapy, which makes this stage complex and singular.

Then, I felt so lost when I lost my hair. Surgery, no. Chemo, no. Because hair was a very important thing to me, because l thought it was very beautiful, I always liked my hair. (P15)

It's weird, if you look at the mirror and see yourself without your hair, you lose some of your identity. (P2)

In the following statement, the stage of hair loss is compared to the stage of breast loss. In both, the alteration of the physical body, with implications for self-image, is experienced.

My hair is falling out for a week, but the physician warned that it would fall out soon. This is another terrible phase. (P16)

After fourteen days, my hair started to fall out, that's the annoying part, because as much as you know it will happen, this ... I have not gotten used to it yet. Although people say it's going to grow again, but I cannot get used to it. " (P11)

Because alopecia is more evident, it generated constraints due to exposure to the perception of the other.

What I found more complicated, which perhaps I would not imagine, that I was going to live, is the relation of prejudice when you happen to use the handkerchief. (P1)

I think this thing is sad ... I wear a scarf to leave the house, but every time I'm with a scarf, I noticed a look of pity on the street, and it was not good forme, you know. I do not want that look. I'd rather wear a wig, and then the person has a doubt. (P14)

The statements revealed that alopecia could cause not only a change in the woman's external image, but also a change in identity. Self-image is related to subjective aspects of the subject, and the body expresses this subjectivity. In this context, the body is understood not as an object, but as a body itself, the instrument of identity and of being-in-the-world.

\section{Fatigue: Merleau-Pontian considerations on the current and habitual body}

Fatigue was revealed as the most limiting symptom, considerably negative, as it alters the life of women in the exercise of their daily activities, interfering with their autonomy. Fatigue can generate feelings of personal devaluation, due to the need to withdraw from work and even domestic activities. In the current context of female pro-activism in various social sectors, the inability to work and to produce is depreciated.

The most difficult for me was that I'm always a person... active. I had an intense life, so what I'm having ... that's learning to deal with the routine. The home routine. I had to find other alternatives so that I did not freak out at the beginning. (P1)

So it was harder for me, at this stage, to take a break. Have a break from this, because you become fragile, because of the medication [...]. But so, I try to live, now, forever, ever, [...] one day at a time. (P4)

I used to stay seven days in bed, with no strength to get up, and had a little feeling of nausea [...]. It was sleep, I could not do anything, I could not open my eyes, I could not get up to go to the bathroom, I could not eat, I did not have the strength. [...] After all that I've been through, I've seen it, we think a lot and see from another angle, so the priorities are different today. (P11)

Red chemo sometimes made me feel a little dizzy. So I had to shorten the office a lot in that period. Those days I stayed very prostrate [...]. (P15)

From the experience of fatigue emerged conceptions that associated the body as a useful object. The body limitations limited all of life, limited the fulfillment of duties, expectations, and desires. One lost her physical condition, but not the habit of keeping up with it, as before.

On the days that I got tired, with the red remedy, it's frustrating that you get tired. You want to work, you want to do things at home, you want to go to work, but [I] could not because I was tired, the body was tired. I was not tired, but the body could not handle it. Then you have to have patience with the donkey [the body]. (P14)

\section{Spirituality: considerations on transcendence from immanence}

The conception of body as object and body as subject emerged from the limitation experienced, and one seeks to overcome this with carefulness, especially spirituality. The body, as subject, does not identify with the limitations experienced by the conditions of its natural body, but uses this immanence to reach transcendence and discover itself as a greater being.

I was psychologically so evolved, I was in a stage so evolved in my life that the breast and the hair for me were not the most important. (P1) 
So, I had already built awareness that I am something beyond the body, right? I have a body, so it's the body that gets sick. Saint Francis of Assisi called his body as my brother donkey" and that's it, my donkey, ... that we must love, that we must be patient with it ... (P14)

The statements revealed that even when you are not identified with the limited body, the experience of limitation that triggered the search for meaning, of being and of life, makes way for the transcendent with the aid of spirituality.

For now, much has changed. During chemotherapy, and for a good time, I think that happy moments have to be lived to the fullest. The coming is to be lived and we have to face it, right, and with great faith - because if we do not have faith, we don't get it. (P5)

I think I'm even more alive than before. ... I'm don't get too upset thank goodness no. I think I'm living a good period of my history, I'm in discovery, in my spiritual part, right ... (P6)

\section{DISCUSSION}

The changes that occur in the body during chemotherapy are complex, as they involve a subject that perceives such changes in a singular way in her existence, in addition to being a biophysical body. A study conducted with women with breast cancer, who analyzed the significance of body changes during and after chemotherapy, concluded that factual changes do not correspond to perceived changes, that is, the perception of body changes is subjective and measurement of changes does not express the self-perception of the woman ${ }^{(13)}$.

The changes in the external image of the woman is a remarkable episode during chemotherapy which corresponds to a transformation in her internal image, that is, the image that the woman has of herself, which is subjective and corresponds to her identity. Health professionals must understand this self-perception to develop effective care. Customized interventions and orientations have more adherences in the female universe, and a comprehensive analysis provides the means to develop them ${ }^{(13-14)}$.

According to Merleau-Ponty, the body is not an object understood only by the physical instance, but it is a body that corresponds to "my personal body", a body of its own, which contains an existence ${ }^{(10)}$. With this, we recognize how dramatic the change in a woman's self-image can be with the loss of her hair. The change of your face, the manner by which you present yourself means a change related to your Being that requires an adaptation with you and the world.

I asked to make the prosthesis; it was very similar to my hair. I think I would have faced more difficulty in treatment if I had not used the prosthesis. (P8)

Many statements have shown the need for adaptation related to one's perception of oneself, which in turn is related to the world and to the other ${ }^{(10)}$. The alternatives that are provided to better cope with this phase consist of guidance and support from the initial moment. It is necessary to know each woman, and her perspective on her face and her identity, as the value of hair as a symbol of feminine beauty is individual, and each woman reacts differently to this phase, which is quite peculiar to all.
To understand these peculiarities is to consider the perception of the body: not of the biophysical body, but the body identity, subject body. Such an understanding prepares health professionals to seek, with the woman, the means that favor her ability to accept, confront, adapt to the new image, and overcome this phase in the way that best suits her. Thus, the wig and scarf indications do not become futilities or a compulsion for the woman, but care that emerge from a singular need.

Confronting the perception of the other is also a relevant issue in this process, and is related to acceptance, trust, and overcoming. Some women do not hide alopecia, others hide it from their husbands, and others hide it only from the unknowns. It is understood that between revealing and hiding alopecia, innumerable feelings and experiences are present, related to the perceptions that exist of oneself and the other.

One participant (P5) opted for cryotherapy on the scalp, a technique that involves cooling the scalp using a thermal cap during chemo, in order to reduce the occurrence of total alopecia. The option for this procedure is currently valued, mainly by women who desire and seek to participate in the decision-making process regarding treatment, which is a new perspective in the power-physician-patient relationship ${ }^{(15)}$. In her statement, she expressed how alopecia would change her life in relation to herself and the other.

I say it's a sense of control that we have of the disease. It is not the disease [...] because when you are bald, you stay in that situation all the time, and with hair you seem to have control of everything. You speak to whomever you want, if you want to talk about what you're going through. You look to the mirror and you do not see a very radical change. So, I'm fine because I have hair. I'm sure if it falls out, emotionally I will get very shaken (P5).

The statement of participant P5, showed that alopecia generates anguish, even more than the mastectomy, because alopecia is more evident and the woman feels estranged and more exposed to the eye of others. Dealing with the perception of others in this context is not only dealing with the aesthetic question, but with any negative connotation that alopecia can express. It has been identified that there is a refusal to be seen as someone less than her entire self, as expressed by P14.

There was a need to react in order to not get sick, because of the social stigma of the disease, the idea of imminent death, and the labels that were created about cancer and chemotherapy that are evident with alopecia. Acceptance, however, provides better conditions for coping with and utilizing strategies that enhance self-perception, as well as the re-signification of her femininity and existence. The perception of the other can be seen more smoothly, as the unveiling of one's own identity has been guided by authenticity ${ }^{(4)}$.

With regards to the second category, the negative impact of fatigue on women's lives is understood from the statements, as innumerable activities are available to which the woman is a responsible and active participant, and the fact that she does not exercise them alters social and financial aspects for the woman and her family. The impact of fatigue is best understood when, as we put ourselves in the order of practical life, it is perceived that the presence of fatigue is the fact that makes the woman feels sick during chemotherapy. It expresses the regretful feeling of no longer living in the rhythm of the world that was perceived. 
The will to have a healthy body, or the refusal of a diseased body, are not formulated by reason, are not of the order of "I think"(10), therefore, the impact of fatigue is not fully understood in the physiological or psychological dimension, but rather from the perspective of being-in-the-world. One needs to appropriate the notion of the current and habitual body, and the considerations of Merleau-Ponty on phantom limb.

The body has two distinct layers: the current body and the habitual body, and he uses the example of the phantom limb to elucidate this idea. The current body is the physiological body whose function is lost when a limb is amputated. The habitual body is the function that remains present even with limb loss, as a kind of latent psyche, in which it is understood that the limb and its function still exist because they are involved in existence, in the habit of being ${ }^{(16)}$.

Existence, therefore, is the dimension in charge of making the union or the interaction between the physiological and the psychological, and realizes the integration of opposites. The dimension that Merleau-Ponty calls existence is, for Heidegger, being-in-the-world. From the perspective of being-in-the-world, we can understand this phenomenon that consists of the engaged consciousness, that holds the practical field that the patient possessed before the loss of the limb. "It is the latent knowledge, which consists of the experience of an ancient present that has not decided to become truly past, but which remains almost present" ${ }^{\prime \prime 16)}$.

From the perspective of being-in-the-world, we understood the negative impact of the fatigue that made the woman feel sick and limited. The limitations caused by fatigue tended to be rejected, and we sought the permanence of the engagement of being in the world, its functions and expectations, in short, its existence. The body expresses this ambiguity, because we can both transcend the physiological condition and we can niilize in the situation that the body imposes ${ }^{(16)}$. It is the intentionality of consciousness, that is, it is going into the world that outlines the existence.

Adaptation to this condition proved to be necessary, not only from the practical point of view related to daily activities, but also from the subjective point of view, of how to live life. In this process, resilience means the ability to deal with a problem in a positive manner, and favors the redefinition of limitations in order to overcome it ${ }^{(17)}$.

The search for the network support of professionals is decisive for overcoming this long phase caused by this symptom. Nurses must develop a plan of holistic care, especially in relation to home care, where the woman, along with her family support network, will demonstrate her needs, as well as those of the family member or the nearest caregiver ${ }^{(18)}$.

The transdisciplinary approach, at the moment, is also crucial to helping identify new potentialities, re-signification of usefulness, and methods of overcoming ${ }^{(4)}$. It is important to avoid dualistic and reductionist attitudes to fatigue, and take care of the practical field to which this phenomenon belongs, to the world of life.

In relation to the third category, the statements demonstrated a self-perception related to the dualistic view of the body, a conception where body and mind are dissociated, as well as the conception of the supremacy of the mind. In this conception, the subject is what she thinks about herself, in spite of the limitation of the body.

In the Merleau-Pontian perspective, however, the body is the subject itself and the body situates the subject in the world, removing it from existential idealism ${ }^{(16)}$. Therefore, the idealization of the subject is intimately related to the body, because, in spite of the constructed idea of "supremacy of the mind", the attitudes are still of adaptation to the conditions of the body, as observed in the statements of P14.

The primacy of perception leads us to consider how we are related to the world, where the subject is her body and her experience in the world, and in this relationship-of-being, the ambiguity of immanence and transcendence is revealed ${ }^{(16,19)}$.

From the perception, in the relationship of the being in the world, one finds the very existence in the scope that is evident (immanence), and in the context that goes beyond itself, against the absolute (transcendence). Therefore, the reach of the transcendent (which is beyond me) passes through immanence (what is in me), both provided by the perception in which the body is subject and not object ${ }^{(16,19)}$.

From this perspective we understand the body's indivisibility and the profound integration of the body and mind, as well as the subject and the world. Such a perspective leads to the realization that I am my body; I am what perception provides to experiment, to live and to idealize. My body is not an object that can be reduced to the idea, but my body "it's me ". If the body becomes ill, the subject becomes ill, and the negation of limitation can be an impediment to overcoming, however, it is a phase of the process of elaborating the loss.

There was, however, the search for the transcendental for overcoming, but intertwined in the biophysical condition. The transcendent does not nullify the present vital condition, but uses it to rise. The perception of the body reveals this ambiguity similar to freedom and slavery. The bad condition of the body is always rejected when it becomes an impediment to being-in-the-world, but the experience of a physical limitation provides the search for the transcendental, and the experience of the transcendental favors the giving of meaning to life.

The search for the transcendent was related to spirituality that provided a search for meaning and answers to fundamental aspects of life. The experience of the sacred and the transcendent can provide health benefits, and are important coping strategies for a cancer diagnosis ${ }^{(20-21)}$.

The understanding of the woman's perception of the experience of chemotherapy provided an understanding of her body concept, revealing the subject in a broad manner, its singularities and sociocultural context. A transdisciplinary approach that is guided by this understanding is essential to give the support that each subject needs to adapt to the new habitual body, and reaches a place that meet her desires.

\section{Limitations of the study}

The limitation of the study is that it was conducted in a single setting, located in the city of Rio de Janeiro, and was based on the perception of the subjects, which implies a lack of national representativeness and impossibility of generalization of the results.

\section{Contributions of the study to the nursing area}

The study provides a reflection that collaborates with the education of health professionals, who should base their practices on human 
perspectives. The study has the possibility of being a bibliographical reference in the field of women's health, oncology, and phenomenology, offering support for teaching, research, and practice.

\section{FINAL CONSIDERATIONS}

The human being is a biopsychosocial, spiritual totality and pursues the transcendental from an experience and awareness of its finitude and physical limitation. The body, in this context, mediates this experience that contemplates immanence and transcendence, not in an opposite way, but totally integrated in the being.

Living the chemotherapy treatment means experiencing many limitations that affect and change the body, that is identity and existence. The change of body and its existential implications perceived by the women in the study, analyzed from the MerleauPontian perspective, make it possible to cover the conception of the body and provide support for humanized care, based on singularity and the sociocultural context.

The phenomenological perspective of the body opens a perspective of a care that is beyond the biophysical, because the human being reflects and transcends his physical perspective and refuses a look that reduces it. Therefore, care is most effective when you first seek understanding of the being and her engagement in the world.

In this complexity, care needs transdisciplinarity, considering the need for a broad support network to care for women with breast cancer. The nurse, however, can be the articulator of the necessary support networks for health promotion and rehabilitation, collaborating within the transdisciplinary care, involving the other sectors of the social life of the woman and creating a climate that provides the quality life that she desires. The understanding of the other as being-in-the-world, and its corporality, translates a holistic vision that is so necessary in teaching and in the practice of care.

\section{FUNDING}

This study was funded by Foundation for Research Support of the State of Rio de Janeiro (FAPERJ - Fundação de Amparo à Pesquisa do Estado do Rio de Janeiro).

\section{REFERENCES}

1. Instituto Nacional de Câncer José Alencar Gomes da Silva (INCA). Estimativa 2016: incidência de câncer no Brasil [Internet]. Rio de Janeiro: INCA; 2015 [cited 2017 Oct 17]. Available from: https://www.inca.gov.br/campanhas/dia-nacional-de-combate-ao-cancer/2015/ estimativa-2016-incidencia-de-cancer-no-brasil

2. Souza CBS, Fustinoni SM, Amorim MHC, Zandonade E, Matos JC, Schirmer J. Breast cancer: diagnosis-to-treatment waiting times for elderly women at a reference hospital of São Paulo, Brazil. Ciênc Saúde Coletiva. 2015;20(12):3805-16. doi: 10.1590/1413-812320152012.00422015

3. Zapponi ALB, Tocantins FR, Vargens OMC. The nurse in the early detection of breast cancer in primary health care. Rev Enferm UERJ. 2015;23(1):33-8. doi: 10.12957/reuerj.2015.11297

4. Paiva ACPC, Salimena AMO, Souza IEO, Melo MCSC. Significado do diagnóstico de neoplasia mamária: compreensão fenomenológica de mulheres. Rev Baiana Enferm. 2015;29(1):59-67. doi: 10.18471/rbe.v29i1.12239

5. Bonassa EMA. Enfermagem em terapêutica oncológica. 4ª ed. São Paulo: Atheneu; 2012.

6. Minayo MCS, Hartz ZMA, Buss PM. Qualidade de vida e saúde: um debate necessário. Ciênc Saúde Coletiva. 2000;5(1):7-18. doi: 10.1590/ S1413-81232000000100002

7. Galdino AR, Pereira LD, Costa Neto SB, Brandão-Souza C, Amorim MHC. Life quality of mastectomized women enrolled in a rehabilitation program. J Res: Fundam Care Online. 2017;9(2):451-8. doi: 10.9789/2175-5361.2017.v9i2.451-458

8. The WHOQOL Group. The World Health Organization quality of life assessment (WHOQOL): position paper from the World Health Organization. Soc Sci Med. 1995; 41(10):1403-9. doi: 10.1016/0277-9536(95)00112-K

9. Matthews E. Compreender Merleau-Ponty. Rio de Janeiro: Vozes; 2010.

10. Merleau-Ponty M. Fenomenologia da percepção. 4a ed. São Paulo: Martins Fontes; 2015.

11. Lima ABM. Merleau-Ponty and the issue of the body in humanities. Saberes Perspect. 2012;2(3):29-49.

12. Faial LCM, Silva RMCRA, Pereira ER, Souza LMC, Bessa RT, Faial CSG. Health at school: phenomenological contributions from the teacher's perception. J Nurs UFPE On Line. 2017;11(1):24-30. doi: 10.5205/reuol.9978-88449-6-1101201704

13. Pedersen B, Groenkjaer M, Falkmer U, Delmar C. Understanding the essential meaning of measured changes in weight and body composition among women during and after adjuvant treatment for breast cancer: a mixed-methods study. Cancer Nurs. 2017;40(6):43344. doi: $10.1097 /$ NCC. 0000000000000427

14. Hartman SJ, Rosen RK. Breast cancer relatives' physical activity intervention needs and preferences: qualitative results. BMC Womens Health. 2017;17:36. doi: 10.1186/s12905-017-0392-0

15. Mahmoodi N, Sargeant S. Shared decision-making - rhetoric and reality: women's experiences and perceptions of adjuvant treatment decision-making for breast cancer. J Health Psychol. 2019;24(8):1082-92. doi: 10.1177/1359105316689141

16. Cardim LN. A ambiguidade na fenomenologia da percepção de Maurice Merleau-Ponty [Tese] [Internet]. São Paulo: Universidade de São Paulo; 2007 [cited 2017 Oct 17]. Available from: http://filosofia.fflch.usp.br/sites/filosofia.fflch.usp.br/files/posgraduacao/ 
defesas/2007_docs/doc_leandroCardim_07.pdf

17. Pinto BK, Muniz RM, Schwartz E, Budó MLD, Heck RM, Lange C. Identidade do homem resiliente no contexto de adoecer por câncer de próstata: uma perspectiva cultural. Rev Bras Enferm. 2014;67(6):942-8. doi: 10.1590/0034-7167.2014670612

18. Wei C, Nengliang Y, Yan W, Qiong F, Yuan C. The patient-provider discordance in patients' needs assessment: a qualitative study in breast cancer patients receiving oral chemotherapy. J Clin Nurs. 2017;26(1-2):125-32. doi: 10.1111/jocn.13374

19. Merleau-Ponty M. O primado da percepção e suas consequências filosóficas. Belo Horizonte: Autêntica; 2015.

20. Pilger C, Santos ROP, Lentsck MH, Marques S, Kusumota L. Spiritual well-being and quality of life of older adults in hemodialysis. Rev Bras Enferm [Internet]. 2017;70(4):689-96. [Thematic Edition "Good Practices: Fundamentals of care in Gerontological Nursing"] doi: 10.1590/0034-7167-2017-0006

21. Freire MEM, Vasconcelos MF, Silva TN, Oliveira KL. Spiritual and religious assistance to cancer patients in the hospital context. Rev Pesqui: Cuid Fundam. 2017;9(2):356-62. doi: 10.9789/2175-5361.2017.v9i2.356-362 